October - 2003

\title{
Editorial
}

\section{Does "lean thinking" relate to network-based distance education?}

\section{Peter S. Cookson}

Pointing to the "objectivised, rationalized, technologically-based interaction," Peters (1973) referred to the then prevailing correspondence forms of distance education as "the most industrialized form of education” (p. 313). With such features as assembly line methods; division of labor; centralized processes of teaching materials development, production and dispatching; student admissions enrollment systems; automated registration, course allocation, and student support, and personnel management systems, distance education institutions demonstrated management structures and practices utilized in industrial and business organizations. Large numbers of courses and students were thus "processed" in correspondence, radio, and televisionbased distance education systems.

Over the past decade or so, there has been a major worldwide expansion of distance education systems, particularly online, Web-based systems. Unlike prior distance education systems, however, network-based distance education models do not so readily accommodate industrialized forms of education. Indeed, the interaction that network-based models enable between students and course content, teachers and peers, sets practical and attenuates the extent to which such teaching-learning transactions may be regarded a form of industrialization.

This divergence from industrial patterns of mass production is further reinforced by, currently in vogue, psychological approaches to learning that encourage abandonment of traditional teacherdirected exposition and passive student assimilation of the structures of objective reality. Constructivism calls for teaching that encourages students' active engagement in the construction of their own cognitive structures and perceptions of reality. To encourage constructivist thinking in the context of network-based distance education, teachers encourage active teacher-student and student-peer dialogue. However, there are practical limits to the number of students with whom an instructor can teach. The finite capacity of teachers to conduct and monitor these different forms of student interaction imposes limits on the capacity of institutions to match the massive numbers of students served by correspondence and mass media-based distance education systems.

Notwithstanding these logistical and practical limits to applications of industrial mass production methods to online distance education at the stage of implementation, such applications continue to be relevant for other stages of distance education design and development. When reliant on print-based course materials, large distance education providers, for example, usually maintain large stockpiles of course materials to be shipped as needed to enrolled students. Production of such materials incurs costs of printing, stockpiling, and warehousing. Printing presses and warehouse facilities occupy space. Materials need to be stored, moved, and processed; sometimes 
Cookson, Vol. 4, No. 2, Editorial: Does "lean thinking" relate to network-based distance education?

they become out of date and must be discarded. Dispatching also involves costs for personnel and scheduling of peak periods associated with inception of classes, followed by periods of inactivity. When classes are scheduled to begin and end on a uniform term schedule, again peak activity for staff members is followed by periods of less activity. In such institutions, scheduling, administration, marking, recording and posting results of admissions and course examinations can be so slow that these procedures keep students in a dispiriting state of limbo for many months. All of these activities involve the common "batch and queue" method of producing in spurts, followed by periods of relative inactivity. Network-based distance education models offer just-intime alternatives.

In the move away from mass media- and correspondence-based distance education systems toward online distance education programmes, a more relevant management approach referred to as "lean thinking" offers guidance for distance education program managers. Owing its origin to the innovative leadership of Taichi Ohno at Toyota Motors in Japan, and popularized by Womack and Jones (2003), lean thinking has enabled industries and public service organizations in many countries to eliminate waste, i.e., "any human activity which absorbs resources but creates no value" (Womack and Jones, 2003, p. 15), lower costs and, at the same time, to increase production. Lean thinking provides "a way to do more and more with less and less - less human effort, less equipment, less time, and less space - while coming closer and closer to providing customers with exactly what they want” (Womack and Jones, 2003, p. 15).

Five core values of lean thinking represent criteria that may be applied to the improvement and evaluation of network-based distance education systems:

1. Identifying those aspects of the educational service learners regard as value is the starting point for lean thinking. Open and distance education programs are in the business of introducing or reinforcing students' connections with learning and opportunity structures. While cultivating meaningful social relationships within a virtual learning community, students are able to improve the quality of their lives and advance their life chances by increasing their knowledge, skills, and other qualifications. From the convenience of their own home or workplace, students may access formal education and continuing education courses without being required to accommodate the location and schedule requirements of educational institutions.

2. Mapping the value stream focuses on tracking the route by which all of the different educational services provided by the institution are transformed from ideas to reality. Increased awareness of how value is produced can enable detection of areas where processes may be simplified, streamlined, and thus become free of waste.

3. Services should flow continuously; the more common "batch and queue" method of service delivery must be avoided. Although in order to assemble networked learning communities of fellow learners, network-based systems often group students in fixed term-length courses, thus retaining the "batch and queue" method, other distance education institutions retain open enrollment arrangements whereby students may begin their courses at any time. In other areas of distance education administration, some institutions have adopted a "just-in-time" approach to printing and testing; they are thus able to produce quick turn around of assignments and test scores. Even just eliminating all forms of "batch and queue" can result in a steady flow of educational services without the periodic strain of responding to peak periods followed periods of relatively low levels of activity. 
Cookson, Vol. 4, No. 2, Editorial: Does "lean thinking" relate to network-based distance education?

4. "Pull" refers to the increased speed with which the educational services flow from the institution to the learners. As examples of non-productive activity are identified and eliminated, the time to produce the educational services is reduced, sometimes dramatically.

5. Perfection in terms of high quality of educational services, with the correspondingly heightened satisfaction of the learners with the value of the services received, becomes attainable for the lean thinking distance education institution.

Explaining how these steps merge in an overall management strategy, Womack and Jones (2003, flyleaf) write:

... Lean thinkers go back to basics by asking what the customer [learner] really perceives as value. . . The next step is to line up value-rating activities for a specific product [service] to line up value-creating activities for a specific product [service] along a value stream while eliminating activities (usually the majority) that don't add value. Then the lean thinker creates a flow condition in which the design and the product [service] advance smoothly and rapidly at the pull of the customer [learner] rather than the push of the producer). Finally, as flow and pull are implemented, the lean thinker speeds up the cycle of improvement in pursuit of perfection.

The concept of "lean thinking" presents a challenge for distance educators. Now that so much of open and distance education is delivered by network-based systems, with their attendant limitations on industrialized forms of education, and the increased application of constructivist approaches to learning, is it time to advance beyond regarding distance education in terms of mass production forms of industrial management? Does lean thinking have a place in the way we administer and manage network-based distance education systems? Does it offer insights for improving the quality of all of our distance education programs, not just those that are networkbased models? How we answer these questions will have lasting consequences for the institutions in which we work, as well as the tens of thousands of students we collectively serve.

\section{References}

Peters, O. (1973). Die didaktische Struktur des Fernunterichts. Untersuchungen zu einer industrialisierten Form des Lehrens und Lernens. Weinheim: Beltz.

Womack, J. P., and Jones, D. T. (2003). Lean Thinking: Banish waste and create wealth in your corporation. Revised and updated. New York: Free Press.

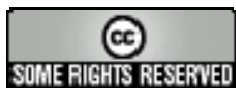

